\title{
PENGARUH JENIS PUPUK ORGANIK DAN UREA TERHADAP PERTUMBUHAN DAN HASIL TANAMAN SELEDRI (Apium graveolus L.)
}

\section{(the Effect of Type of Organic Fertilizers and Urea on the Growthand Yield of Celery (Apium graveolens L.))}

\author{
Netty Syam ${ }^{1}$, Suriyanti ${ }^{1}$ dan Lilla Hasni Killian ${ }^{2}$ \\ ${ }^{1)}$ Fakultas Pertanian Universitas Muslim Indonesia Makassar \\ ${ }^{2)}$ Alumni Fakultas Pertanian Universitas Muslim Indonesia Makassar \\ E-mail: nettysyam@gmail.com
}

\begin{abstract}
The objectives of the research were to find out type of organic fertilizer and urea doses to improve the yield of celery. The experiment was arranged using Randomized Block Design with factorial design.The first factor were cow manure, compost and chicken manure and the second factor were urea dosage 240 $\mathrm{kg} / \mathrm{ha}, 270 \mathrm{~kg} / \mathrm{ha}$ and $300 \mathrm{~kg} / \mathrm{ha}$.The results showed that organic fertilizer treatment in the form of chicken manure and urea $300 \mathrm{~kg} / \mathrm{ha}$ resulted in plant height, leaf number, number of tillers, root volume and wet weight in celery were highst. The highest number of tillers was 6.27 plants and wet weight $14.69 \mathrm{~g}$ per plant.
\end{abstract}

Keywords: celery, organic fertilizer, urea

\section{PENDAHULUAN}

Seledri merupakan salah satu tanaman sayuran penting dan memiliki nilai ekspor. Selain sebagai tanaman sayuran, seledri juga digunakan sebagai bumbu yang sangat digemari masyarakat, baik di Indonesia maupun di negaranegara Eropa, Amerika dan Asia.Tanaman ini juga dimanfaatkan sebagai bahan obatobatan dan kosmetik, karena dalam daunnya banyak mengandung saponin, flavonoida dan polifenol. Untuk obatobatan ,misalnya untuk mengobati tekanan darah tinggi, urine keruh (chyloria), pencegah masuk angin dan penghilang rasa mual (Permadi, 2006).
Seledri mengandung emustral dan kolesterol yang digunakan untuk menyuburkan dan menghitamkan rambut sehingga seledri dapat digunakan sebagai bahan shampo dan cream bath (Permadi, 2006).

Tanaman seledri juga banyak mengandung vitamin $\mathrm{A}$, vitamin $\mathrm{C}$ dan zat besi serta zat gizi lainnya yang cukup tinggi. Dalam $100 \mathrm{~g}$ bahan mentah, seledri mengandung $130 \mathrm{IU}$ vitamin $\mathrm{A}, 0,03 \mathrm{mg}$ vitamin $\mathrm{B}, 0,9 \mathrm{~g}$ protein, 0,1 g lemak, $4 \mathrm{~g}$ karbohidrat, 0,9 g serat, $50 \mathrm{mg}$ kalsium, 1 $\mathrm{mg}$ besi, 0,005 $\mathrm{mg}$ riboflavin, 0,003 mg tiamin, 0,4 $\mathrm{mg}$ nikotinamid, $15 \mathrm{mg}$ asam askorbat dan $95 \mathrm{ml}$ air (Anonim, 1992). 
Permintaan seledri dari tahun ke tahun terus mengalami peningkatan baik permintaan domestik maupun dari luar negeri. Peningkatan permintaan dari luar negeri mungkin disebabkan oleh semakin berkurangnya lahan pertanian akibat konversi lahan sehingga dialihkan ke negara berkembang yang lahannya masih luas dengan tenaga kerja yang relatif murah, serta kondisi iklim yang kurang mendukung terutama saat musim dingin dan musim gugur sehingga praktis semua kebutuhan sayuran untuk masyarakatnya tergantung dari negara-negara lain (Anonim, 1992). Untuk memenuhi kebutuhan tersebut, maka perlu dilakukan peningkatan hasil,baik melalui ekstensifikasi maupun intensifikasi.

Salah satu peningkatan hasil melalui intensifikasi adalah dengan pemilihan media tumbuh dan pemupukan. Media tumbuh merupakan salah satu unsur penting dalam menunjang pertumbuhan tanaman, karena sebagian besar unsur hara yang dibutuhkan tanaman, dipasok melalui media tumbuh, selanjutnya diserap oleh akar dan digunakan untuk pertumbuhan tanaman. Menurut Soetomo (1996), media tumbuh adalah tempat akar tanaman tumbuh dan mengisap zat makanan untuk pertumbuhannya serta tempat memperkokoh berdirinya tanaman, sehingga di dalam media tumbuh harus tersedia unsur hara yangdibutuhkan tanaman. Bahan-bahan untuk media tumbuh dapat dibuat dari bahan tunggal ataupun kombinasi dari beberapa bahan, asalkan tetap berfungsi sebagai media tumbuh yang baik (Wira, 2000) dan jenis media tumbuh yang berbedaakan memberikan pengaruh yang berbeda terhadap pertumbuhan tanaman (Hajrah, 1997).

Seledri yang disemaikan dengan biji, biasanya membutuhkan waktu yang lama untuk tumbuh, sehingga diperlukan media tumbuh yang sesuai, dengan harapan tanaman dapat terhindar dari kematian. Informasi tentang media yang sesuai untuk tanaman seledri sampai saat ini masih kurang. Selain media, pemupukan diperlukan puladalam usaha untukmeningkatkan hasil. Pemupukan adalah setiap usaha pemberian pupuk yang bertujuan menambah persediaan unsur-unsur hara yang dibutuhkan oleh tanaman (Sarief, 1986).

Teknologi pemupukan adalah salah satu penentu dalam upaya meningkatkan kualitas dan kuantitas hasil pertanian, penggunaan pupuk yang sesuai diharapkan dapat mencapai tingkat produksi yang 

(Apium Graveolus L.)

secara ekonomis menguntungkan. unsur maka pupuk ini pun mengandung Pemupukan hakikatnya merupakan hampir semua unsur (baik makro maupun pemberian unsur hara kedalam tanah mikro). Hanya saja, ketersediaan unsur sehingga kebutuhan tanaman akan unsur tersebut biasanya dalam jumlah yang hara dapat terpenuhi. Namun jenis dan sedikit. Pupuk organik atau bahan organik dosis pemupukan merupakan faktor yang tanah merupakan sumber nitrogen tanah harus diperhatikan karena setiap tanaman yang utama, selain itu peranannya cukup memiliki karakteristik yang berbeda besar terhadap perbaikan sifat fisika, terhadap pemupukan. Pemupukan baik kimia biologi tanah serta lingkungan. jenis, dosis, dan waktu pemberian sangat berpengaruh terhadap pertumbuhan dan produksi tanaman seledri. Unsur nitrogen dan penggunaan pupuk organik pada pertumbuhan awal sampai akhir terus diperlukan (Sumarno dkk. 2001).

Sumber utama bahan organik bagi tanah berasal dari jaringan tanaman, baik berupa serasah ataupun sisa-sisa tanaman mati. Bahan-bahan organik yang berasal dari serasah, sisa-sisa tanaman yang mati, limbah atau kotoran hewan dan bangkai hewan itu sendiri, didalam tanah akan terdekomposisi dan dipindahkan oleh jasad renik yang selanjutnya dengan kegiatan berbagai jasad tanah bahan organik itu melalui berbagai proses yang rumit dirombak menjadi bahan organik tanah yang mempunyai arti penting (Sutejo dan Kartasapoetra, 1987).

Pupuk organik berasal dari bahan organik yang mengandung segala macam peningkatan produksi pertanian baik kualitas maupun kuantitas, mengurangi pencemaran lingkungan, dan meningkatkan kualitas lahan secara berkelanjutan. Penggunaan pupuk organik dalam jangka panjang dapat meningkatkan produktivitas lahan dan mencegah degradasi lahan. Namun pupuk organik memiliki kadar unsur hara yang rendah, kelarutan rendah, waktu lebih relatif lama menghasilkan nutrisi tersedia yang siap diserap tanaman, dan respon tanaman terhadap pemberian pupuk organik tidak sebaik pupuk anorganik. Sehingga pupuk organik tidak banyak digunakan, karena dianggap tidak memenuhi kebutuhan nutrisi tanaman (Musnamar, 2005). Pupuk organik yang ditambahkan ke dalam tanah akan mengalami beberapa kali fase perombakan oleh mikroorganisme tanah 
untuk menjadi humus atau bahan organik tanah.

Selain pemberian pupuk organik, pemberian pupuk urea sebagai sumber hara nitrogen $(\mathrm{N})$ merupakan usaha yang banyak dilakukan dalam meningkatkan produktivitas sayuran daun khususnya seledri. Pupuk urea sebagai sumber hara $\mathrm{N}$ dapat memperbaiki pertumbuhan vegetatif tanaman, dimana tanaman yang tumbuh pada tanah yang cukup N, berwarna lebih hijau (Hardjowigeno, 1987). Akan tetapi penggunaan urea yang berlebihan pada tanah akan dapat merusak kondisi kesuburan tanah.

Penggunaan pupuk organik yang dipadukan dengan penggunaan pupuk kimia dapat meningkatkan produktivitas tanaman dan pengurangan penggunaan pupuk kimia, baik pada lahan sawah maupun lahan kering. Telah banyak dilaporkan bahwa terdapat interaksi positif pada penggunaan pupuk organik dan pupuk kimia secara terpadu. Penggunaan pupuk kimia secara bijaksana diharapkan memberikan dampak yang lebih baik di masa depan. Tidak hanya pada kondisi lahan dan hasil panen yang lebih baik, tetapi juga pada kelestarian lingkungan (Musnamar, 2005). Untuk itu perlu dilakukanpenelitian untuk mendapatkan jenis pupuk organik yaitu pupuk kandang sapi, kompos dan pupuk kandang ayam dan dosis urea dalam meningkatkan pertumbuhan dan produksi tanaman seledri. Penelitian ini diharapkan dapat dijadikan acuan dalam peningkatan produksi tanaman seledri dan sebagai informasi bagi peneliti berikutnya.

\section{METODE PENELITIAN}

Penelitian ini dilaksanakan di Kelurahan Sudiang, Makassar yang berlangsung dari bulan Maret sampai dengan bulan Agustus 2016 dalam bentuk percobaan pot dan disusun berdasarkan Rancangan Acak Kelompok (RAK) pola faktorial. Faktor pertama adalah jenis pupuk organik yaitu pupuk kandang sapi, pupuk kompos dan pupuk kandang ayam masing-masing 65 ton/ha yang setara dengan 100 g/pot.Faktor kedua adalah pemberian urea dosis $240 \mathrm{~kg} / \mathrm{ha}(0,35$ g/pot), $270 \mathrm{~kg} / \mathrm{ha}(0,40 \mathrm{~g} / \mathrm{pot})$ dan 300 $\mathrm{kg} / \mathrm{ha}(0,45 \mathrm{~g} / \mathrm{pot})$ yang diulang $3 \mathrm{kali}$ dan setiap perlakuan, terdapat 3 tanaman/pot.

Benih seledri ditaburkan secara merata pada media tanah dan pasir dengan perbandingan $2: 1$ dan disiram merata. Bibit tersebut dipelihara selama 14 hari (2-4 helai daun) dan selanjutnya dipindahkan ke pot penelitian. 
Pot diisi penuh dengan tanah dan pupuk organuk sesuai dengan perlakuan dengan volume $3 \mathrm{~kg} /$ pot. Pemindahan bibit dilakukan pada sore hari, hal ini agar tidak terjadi evapotranspirasi yang berlebihan. Sebelum tanaman dipindahkan pada media tanam terlebih dahulu di lembabkan. Pemeliharaan dilakukan dengan cara menyiram setiap hari dua kali pada waktu pagi dan sore sesuai kebutuhan. Urea diberikan pada tanaman seledri sesuai dengan perlakuan. Panen dilakukan pada saat tanaman sudah berumur 7 minggu setelah tanaman (MST).Pengamatan yang dilakukan adalah tinggi tanaman $(\mathrm{cm})$, jumlah daun (helai), jumlah anakan (tanaman), volume akar (ml) dan bobotbasah tanaman (g).

Data pertumbuhan dan produksi yang diperoleh dianalisisdengan Analisis
Sidik Ragam pada taraf 5 persen. Jika terdapat pengaruh nyata, dilanjutkan dengan uji Beda Nyata Jujur pada taraf yang sama.

\section{HASIL DAN PEMBAHASAN}

Hasil penelitian pada Tabel 1 menunjukan bahwa perlakuan urea dan pupuk organik memberikan interaksi yang pengaruh nyata terhadap tinggi tanaman seledri. Hasil uji BNJ 0,05 menunjukan bahwa pupuk kandang ayam + urea 300 $\mathrm{kg} / \mathrm{ha}(0,45 \mathrm{~g} / \mathrm{pot})$ memberikan pengaruh terbaik pada tinggi tanaman yaitu 21,58 cm. Hasil terendah ditunjukkan pada penggunaan pupuk kandang sapi + urea $240 \mathrm{~kg} / \mathrm{ha}(0,35 \mathrm{~g} / \mathrm{pot})$ dengan rata-rata tinggi tanaman $8,17 \mathrm{~cm}$.

Tabel 1. Rata-rata pertambahan tinggi tanaman seledri pada pemberian pupuk organik dan urea umur 7 MST

\begin{tabular}{|c|c|c|c|c|c|}
\hline \multirow[t]{2}{*}{ Jenis pupuk organik } & \multicolumn{3}{|c|}{ Dosis urea $(\mathrm{kg} / \mathrm{ha})$} & \multirow{2}{*}{$\begin{array}{c}\text { Rata- } \\
\text { rata }\end{array}$} & \multirow{2}{*}{$\begin{array}{c}\text { NPBNJ } \\
5 \%\end{array}$} \\
\hline & 240 & 270 & 300 & & \\
\hline Pupuk kandang sapi & $8,17^{\mathrm{d}}$ & $9,28^{\mathrm{cd}}$ & $9,47^{\mathrm{bc}}$ & 8,97 & \\
\hline Kompos & $10,29^{\mathrm{d}}$ & $9,58^{\mathrm{cd}}$ & $12,14^{\mathrm{b}}$ & 10,67 & 5,35 \\
\hline Pupuk kandang ayam & $13,73^{\mathrm{bc}}$ & $16,55^{\mathrm{ab}}$ & $21,58^{\mathrm{a}}$ & 17,29 & \\
\hline Rata-rata & 10,73 & 11,8 & 14,4 & & \\
\hline
\end{tabular}


Tabel 2. Rata-rata jumlah daun seledri pada pemberian pupuk organik dan urea umur 7 MST

\begin{tabular}{lccccc}
\hline Jenis pupuk organik & \multicolumn{3}{c}{ Dosis urea $(\mathrm{kg} / \mathrm{ha})$} & Rata- & NPBNJ \\
\cline { 2 - 4 } & 240 & 270 & 300 & rata & $5 \%$ \\
\hline Pupuk kandang sapi & $24,23^{\mathrm{c}}$ & $25,50^{\mathrm{b}}$ & $25,50^{\mathrm{b}}$ & 25,08 & \\
Kompos & $29,95^{\mathrm{a}}$ & $27,23^{\mathrm{ab}}$ & $26,61^{\mathrm{b}}$ & 27,93 & 5,35 \\
Pupuk kandang ayam & $25,36^{\mathrm{bc}}$ & $30,41^{\mathrm{a}}$ & $38,68^{\mathrm{a}}$ & 31,48 & \\
\hline \multicolumn{1}{c}{ Rata-rata } & 26,51 & 27,71 & 30,26 & & \\
\hline
\end{tabular}

Keterangan: Nilai rata-rata yang diikuti oleh huruf $(a, b, c, d)$ yang berbeda nyata berarti berbeda nyata pada taraf $\alpha=0,05$.

Tabel 3. Rata-rata jumlah anakan seledri pada pemberian pupuk organik dan urea umur 7 MST

\begin{tabular}{lccccc}
\hline Jenis pupuk organik & \multicolumn{3}{c}{ Dosis urea $(\mathrm{kg} / \mathrm{ha})$} & Rata- & NPBNJ \\
\cline { 2 - 4 } & 240 & 270 & 300 & rata & $5 \%$ \\
\hline Pupuk kandang sapi & $2,06^{\mathrm{ab}}$ & $2,68^{\mathrm{b}}$ & $3,03^{\mathrm{b}}$ & 2,59 & \\
Kompos & $2,62^{\mathrm{ab}}$ & $2,98^{\mathrm{b}}$ & $2,72^{\mathrm{b}}$ & 2,77 & 5,35 \\
Pupuk kandang ayam & $3,10^{\mathrm{b}}$ & $3,47^{\mathrm{b}}$ & $6,27^{\mathrm{a}}$ & 4,28 & \\
\hline \multicolumn{1}{c}{ Rata-rata } & 2,59 & 3,04 & 4,01 & & \\
\hline
\end{tabular}

Keterangan: Nilai rata-rata yang diikuti oleh huruf $(a, b, c, d)$ yang berbeda nyata berarti berbeda nyata pada taraf $\alpha=0,05$

Interaksi antara jenis pupuk organik dan pupuk urea memberikan pengaruh nyata terhadap pertumbuhan jumlah daun tanaman seledri dan hasil uji BNJ 0,05 menunjukan bahwa pupuk kandang ayam + urea $300 \mathrm{~kg} / \mathrm{ha}$ memberikan pengaruh terbaik pada jumlah daun tanaman seledri yaitu 38,68 helai, sedangkan hasil terendah ditunjukkan pada pemberian pupuk kandang sapi + urea $240 \mathrm{~kg} / \mathrm{ha}$ yaitu 24,23 helai yang ditampilkan pada Tabel 2.
Selanjutnya, hasil pengamatan jumlah anakan dan sidik ragam menunjukan bahwa interaksi penggunaan jenis pupuk organik dan pupuk urea memberikan pengaruh sangat nyata pada pertambahan jumlah anakan pada tanaman seledri. Tabel 3 menunjukan bahwa perlakuan pupuk kandang ayam + urea $300 \mathrm{~kg} / \mathrm{ha}$ memberikan pengaruh terbaik pada jumlah anakan yaitu 6,27 anakan, sedangkan hasil terendah ditunjukkan 
pada pupuk kandang sapi + urea 240 menunjukkan bahwa aplikasi pupuk $\mathrm{kg} / \mathrm{ha}$ dengan jumlah anakan 2,06 anakan. kandang ayam + urea $300 \mathrm{~kg} / \mathrm{ha}$ Berbeda dengan parameter cenderung memper lihatkan bobot basah sebelumnya, hasil analisis sidik ragam tanaman seledri yang lebih tinggi yaitu volume akar menunjukan bahwa $14,67 \mathrm{~g}$, sedangkan yang terendah yaitu penggunaan jenis pupuk organik dan dosis 4,57 $\mathrm{g}$ diperoleh dari aplikasi pupuk urea serta interaksi antara keduanya kandang sapi + urea $240 \mathrm{~kg} / \mathrm{ha}$.

memberikan pengaruh yang tidak nyata Pemberian pupuk kandang ayam terhadap volume akar pada tanaman pada tanaman seledri memberikan seledri. Namun pada Gambar 1 pengaruh terbaik terhadap pertumbuhan memperlihatkan adanya volume akar yang dan produksi tanaman seledri karena cenderung lebih tinggi pada perlakuan pupuk kandang ayam lebih cepat terurai pupuk kandang ayam + urea $300 \mathrm{~kg} / \mathrm{ha}$ dibandingkan pupuk kandang yang lain. yaitu 3,49 ml, sedangkan yang terendah Menurut Subroto (2009) bahwa pemberian yaitu $0,93 \mathrm{ml}$ ditunjukkan pada aplikasi pupuk kotoran ayam dapat memperbaiki pupuk kandang sapi + urea $240 \mathrm{~kg} / \mathrm{ha}$.

Hal yang serupa juga terjadi pada sidik ragam bobot basah tanaman seledri yang menunjukan bahwa penggunaan jenis pupuk organik dan dosis urea serta interaksi antara keduanya memberikan struktur tanah yang sangat kekurangan unsur organik serta dapat memperkuat akar tanaman. Pupuk kandang kotoran ayam mengandung $\mathrm{N}$ tiga kali lebih banyak dari pupuk kandang lainnya (Hardjowigeno,1995).

pengaruh yang tidak nyata. Gambar 2 


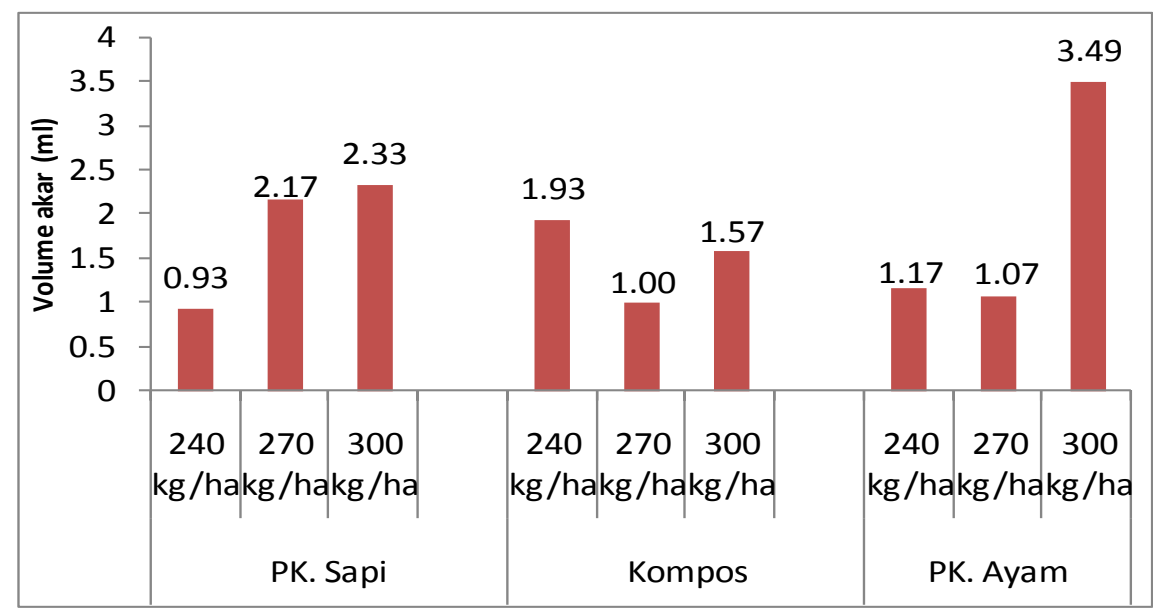

Gambar 1. Rata-rata volume akar tanaman seledri pada pemberian pupuk organik dan urea umur 7 MST.

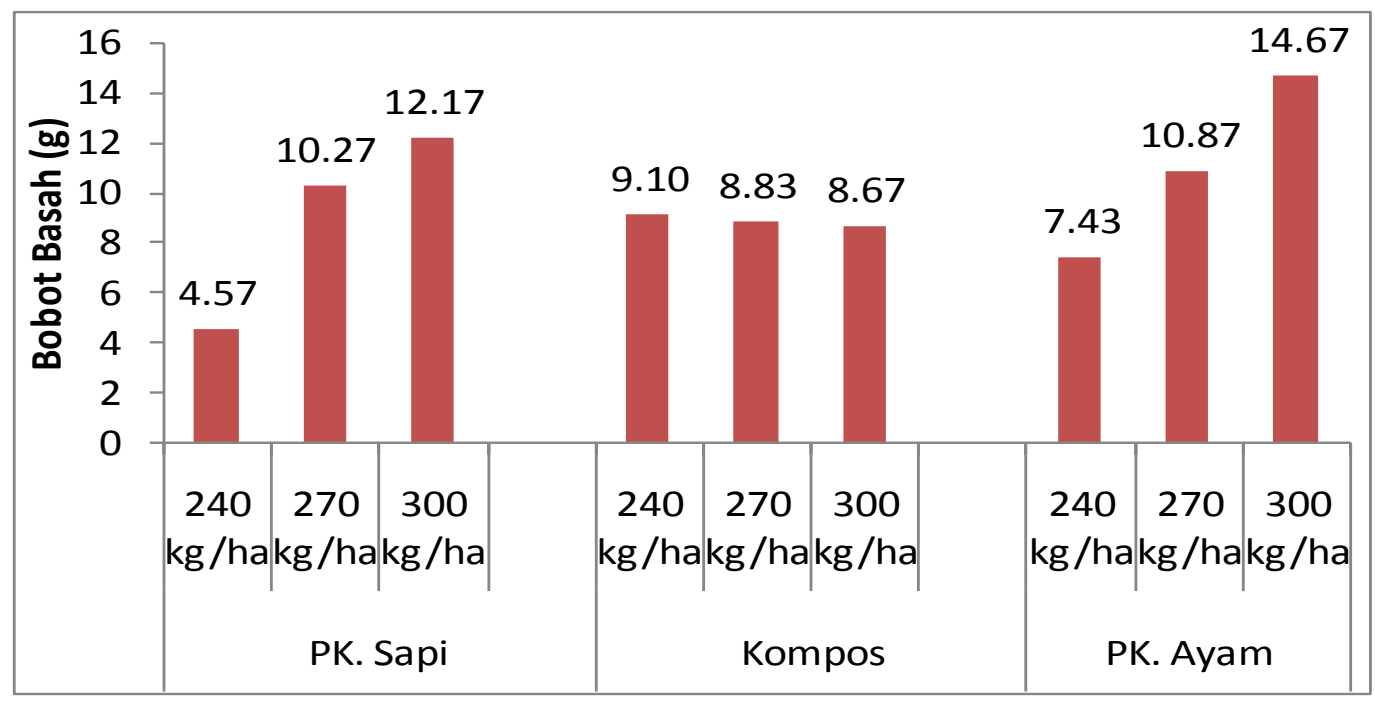

Gambar 2. Rata-rata bobot basah tanaman seledri pada pemberian pupuk organik dan urea umur 7 MST.

Beberapa hasil penelitian, aplikasi dengan pupuk kandang yang lainnya pupuk kandang ayam selalu memberikan (Widyowatiet al, 2004). Dibandingkan respon tanaman yang terbaik pada musim dengan bahan organik lain pupuk kandang pertama. Hal ini terjadi karena pupuk ayam memiliki kandungan $\mathrm{N}$ yang cukup kandang ayam relatif lebih cepat tinggi yaitu 2,6\%, 2,9\% (P), dan 3,4\% (K) terdekomposisi serta mempunyai kadar dengan perbandingan $\mathrm{C} / \mathrm{N}$ ratio 8,3 hara yang cukup pula jika dibandingkan (Zakaria dan Vimala, 2002). Hal ini 
diperkuat dengan hasil penelitian (Sutejo 2002) yang mengemukakan bahwa pupuk kandang ayam mengandung nitrogen tiga kali lebih besar dari pada pupuk kandang yang lainnya.Lebih lanjut dikemukakan kandungan unsur hara dari pupuk kandang ayam lebih tinggi karena bagian cair (urine) bercampur dengan bagian padat.Pupuk kandang ayam memberikan pengaruh yang baik terhadap perbaikan sifat fisik dan kimia tanah.Pupuk kandang selain mengandung nitrogen, fosfor dan kalium, juga mengandung beberapa unsur mikro dan sejumlah besar bahan organik (Ghafoor et al, 2003).

Pupuk kandang ayam secara umum mempunyai kelebihan dalam kecepatan penyerapan hara, komposisi hara seperti $\mathrm{N}, \mathrm{P}, \mathrm{K}$ dan $\mathrm{Ca}$ dibandingkan pupuk kandang sapi dan kambing (Widowati, 2004).Pengunaan pupuk kandang ayam berfungsi untuk memperbaiki struktur fisik dan biologi tanah, menaikkan daya serap tanah terhadap air.

Pemberian pupuk kandang berpengaruh dalam meningkatkan Al-dd dan menurunkan $\mathrm{pH}$, hal ini disebabkan karena bahan organik dari pupuk kandang dapat menetralisir sumber kemasaman tanah. Pupuk kandang juga akan menyumbangkan sejumlah hara kedalam tanah yang dapat berfungsi guna menunjang pertumbuhan dan perkembangannya, seperti N, P, K (Djafaruddin, 1970).

Aplikasi urea $300 \mathrm{~kg} / \mathrm{ha}$ juga memperlihatkan pengaruh tebaik terhadap komponen pengamatan pertumbuhan ratarata tinggi tanaman, dan jumlah anakan. Pupuk urea adalah pupuk yang mengandung nitrogen $(\mathrm{N})$ berkadar tinggi. Unsur Nitrogen merupakan zat hara yang sangat diperlukan tanaman.Unsur nitrogen didalam pupuk urea sangat bermanfaat bagi tanaman untuk pertumbuhan dan perkembangan. Manfaat lainnya antara lain pupuk urea membuat daun tanaman lebih hijau, rimbun, dan segar. Nitrogen juga membantu tanaman sehingga mempunyai banyak zat hijau daun (klorofil). Dengan adanya zat hijau daun yang berlimpah, tanaman akan lebih mudah melakukan fotosintesis, pupuk urea mempercepat pertumbuhan tanaman (tinggi, jumlah anakan, cabang dan lainlain) dan urea juga mampu menambah kandungan protein di dalam tanaman (Suhartono, 2012).

Interaksi antara pupuk kandang ayam dan urea $300 \mathrm{~kg} / \mathrm{ha}$ memperlihatkan pengaruh yang signifikan terhadap tinggi tanaman, jumlah daun dan jumlah anakan, 
namun tidak memberikan pengaruh yang signifikan terhadap volume akar dan bobot basah. Dibandingkan dengan pupuk kandang sapi dan kompos, aplikasi pupuk kandang ayam selalu memberikan respon tanaman yang terbaik. Hal ini terjadi karena pupuk kandang ayam relatif lebih cepat terdekomposisi serta mempunyai kadar hara yang cukup jika dibandingkan dengan pupuk kandang yang lainnya (Widyowati, et al. 2004). Sedangkan pupuk kandang sapi dan pupuk kompos memiliki kadar $\mathrm{C}$ yang tinggi. Tingginya kadar C dalam pupuk kandang sapi dan kompos menghambat penggunaan langsung ke lahan pertanian karena akan menekan pertumbuhan tanaman. Penekanan pertumbuhan terjadi karena mikroba dekomposer akan menggunakan $\mathrm{N}$ yang tersedia untuk mendekomposisi bahan organik tersebut sehingga tanaman akan kekurangan N. Untuk memaksimalkan penggunaan pupuk kandang sapi harus dikomposkan lebih dahuluhingga mencapai rasio $\mathrm{C} / \mathrm{N}$ di bawah 20 (Hartatik dan Widowati, 2010).

Dari 9 kombinasi perlakuan yang digunakan hasil penelitian menunjukan interaksi antara dosis urea dan jenis pupuk organik yang terbaik yaitu pupuk kandang ayam dan urea $300 \mathrm{~kg} / \mathrm{ha}$ memperlihatkan pertumbuhan tanaman terbaik Sedangkan pertumbuhan tanaman yang kurang baik atau tidak maksimal yaitu pada pemberian pupuk kandang sapidan urea $240 \mathrm{~kg} / \mathrm{ha}$.

Komposisi unsur hara pada pupuk kandang sapi padat terdiri atas campuran $0,40 \% \quad \mathrm{~N}, 0,20 \% \quad \mathrm{P}_{2} \mathrm{O}_{5}$ dan $0,10 \% \quad \mathrm{~K}_{2} \mathrm{O}$. Pupuk kandang yang sudahsiap digunakan apabila tidak terjadi lagi penguraian oleh mikroba. Pupuk kandang dapat diberikan sebagai pupuk dasar, yakni dengan cara menebarkan secara merata di seluruh lahan. Khusus bagi tanaman dalam pot, pupuk kandang diberikan sepertiga dari media dalam pot (Lingga, 1994).

\section{KESIMPULAN}

Penggunaan pupuk organik berupa pupuk kandang ayam dan urea $300 \mathrm{~kg} / \mathrm{ha}$ menghasilkan tinggi tanaman, jumlah daun, jumlah anakan, volume akar dan bobot basah tertinggi pada tanaman seledri. Jumlah anakan tertinggi yang diperoleh yaitu 6,27 tanaman dan bobot basah $14,69 \mathrm{~g}$ per tanaman.

\section{DAFTAR PUSTAKA}

Anonim. 1992. Sayur Komersial. PT. Penebar Swadaya, Jakarta. 97 h.

Hajrah S., 1997. Pengaruh Macam Media Tumbuh Dalam Teknik Hidroponik 
terhadap Pertumbuhan dan Hasil Tanaman Paprika.Skripsi. Fakultas Pertanian, Universitas Mataram.

Hardjowigeno, S. 1987. Ilmu Tanah. PT. Medyatamasarana Perkasa. Jakarta. HIm : 73-76.

Hartatik W. dan L.R. Widowati. 2006. Pupuk Kandang.Balai Besar Litbang Sumberdaya Lahan Pertani- an, Badan Penelitian dan Pengembangan Pertanian. h. 59-82.

Lingga, P. 1989. Petunjuk Penggunaan

Musnamar, 2005.Pupuk organik. Penebar Swadaya. Jakarta.

Permadi, A. 2006.36 Resep Tumbuhan Obat untuk Menurunkan Kolesterol. Penebar Swadaya, Jakarta.

Sarief, E.S., 1986. Kesuburan dan Pemupukan Tanah Pertanian. Pustaka Buana, Bandung. 182 h.

Soetomo, V.I., 1996. Pengaruh penambahan kompos dan pupuk urea terhadap pertumbuhan dan produksi Jamur Tiram Putih.Skripsi, Fakultas Pertanian, UMM, Malang.

Subroto.2009.Kesuburan dan Pemupukan Tanah Pertanian. Bandung: Pustaka Buana.

Suhartono, 2012, Unsur-unsur nitrogen dalampupuk urea, UPN Veteran Yogyakarta.

Sutedjo, M.M. dan Kartasapoetra, A. G., 1987. Konservasi Tanah dan Air. Bina Aksara, Jakarta.
Wira, N.J., 2000. Pengaruh Campuran Bahan Organik Terhadap Pertumbuhan dan Hasil Tanaman Seledri. (Skripsi), Fakultas Pertanian. Universitas Mataram 149h. 